Review Article

\title{
Reliability and credibility analysis of Inlow's 60 second diabetic foot screening tool for diabetic foot risk stratification and its feasibility in India: a systematic review
}

\author{
Madhivadhanam Parasuraman, Bhanumati Giridharan*, G. Vijayalakshmi
}

Department of General Surgery, ESIC Medical College and PGIMSR, KK Nagar, Chennai -78, Tamil Nadu, India

\author{
Received: 08 July 2017 \\ Accepted: 04 August 2017 \\ *Correspondence: \\ Dr. Bhanumati Giridharan, \\ E-mail: dr.bhanumati@gmail.com
}

Copyright: () the author(s), publisher and licensee Medip Academy. This is an open-access article distributed under the terms of the Creative Commons Attribution Non-Commercial License, which permits unrestricted non-commercial use, distribution, and reproduction in any medium, provided the original work is properly cited.

\begin{abstract}
Diabetes is the common cause for amputation of lower limb. Foot ulcers and associated complications are important causes of mortality and morbidity in patients with diabetes. Hence, it is important to predict diabetic foot ulcer in its early stages to eliminate the risks of foot amputation. Inlow's 60 second diabetic foot ulcer screening tool is gaining immense attention over the years which is associated with its simplicity to use, rapid detection of high risk diabetic feet, and provides referral for patients necessitating treatment. A systematic review is conducted to assess the reliability and credibility of using Inlow's 60 second diabetic foot screening tool for diabetic foot risk stratification and to examine its feasibility in the Indian context. Eight studies suited the inclusion criteria which were analysed systematically. The findings of the paper reveal that the sixty second tool acts as a better tool for diabetic foot ulcer risk stratification; however, modifications are necessary for its application in the Indian context.
\end{abstract}

Keywords: Credibility, Diabetic foot ulcer, Inlow's 60 second tool, Reliability

\section{INTRODUCTION}

Diabetes is a global concern; there is an increase in the number of diabetic patients all over the world and diabetes related complications are increasing such as the non-traumatic lower extremity amputations. ${ }^{1}$ Mostly, diabetic foot complications which lead to the amputation of foot are associated with the formation of skin ulcers in diabetic patients. ${ }^{2}$ It is hence of crucial importance to detect Diabetic Foot Ulcers (DFU) in its early stages to prevent amputations of the lower limb in diabetic patients.

There is an increase in the prevalence of DFUs all over the world wherein the most specific countries that are affected to the core belong to Africa, Asia and South America. ${ }^{3}$ The nature of DFUs is generally neuropathic and hence is simple to prevent and treat during its initial stages. ${ }^{3-6}$ A quarter of people with diabetes is estimated to develop foot ulcer wherein reports reveal a lower limb is amputated every 30 seconds as a result of DFU complication. ${ }^{7,8}$ In the diabetic population, amputations frequently occur at 15-40 times than in normal population. Hence, it is of vital importance to define and utilize a standardized approach for the efficient prevention of foot ulceration which ultimately reduces the risks of amputation. The first step is hence the correct identification of foot ulceration and the degree of risks in patients. $^{9}$

Presently, there are several diabetes foot risk stratification systems which utilise different methods. ${ }^{10}$ Diabetic foot risk stratification identifies the various clinical features of patients with diabetes that predict the risks of foot ulceration in the future. Several clinical indicators include both the peripheral and systemic symptoms and signs. 
Systemic signs include age, gender, body-mass index (BMI), height, weight, diabetes duration, diabetes type, regimes of insulin, fasting glucose, history of myocardial infarct, serum creatinine, kidney diseases, alcohol consumption, smoking and so on. Peripheral features include deformity of the foot, abnormal plantar foot pressure, peripheral neuropathy, prior foot amputation or ulceration, absence of tendon reflexes, transcutaneous oxygen tension, tineapedis, onychomycosis, fissured skin and lower leg oedema. ${ }^{11}$ In addition, social factors also contribute to the clinical indicators which include occupation, education, religion, marital status, ethnicity, and so on. ${ }^{11,12}$

Several diabetic foot ulcer risk stratification tools have been developed over the years wherein a systematic review by Monteiro-Soares et al, reveals the following: International Working Group on Diabetic Foot (IWGDF), University of Texas Foot Risk Stratification (UTFRS), Scottish Intercollegiate Guideline Network (SIGN), American Diabetes Association (ADA) and a tool developed by Boyko et al. ${ }^{12,13}$

Of all these tools, only Boyko et al, examined predictive validity through an external system wherein $\mathrm{HbA1c}$ is considered as a predictive variable. ${ }^{12,13}$ However, predictive validity is highly examined in the tool developed by Inlow, wherein various researches examined the reliability and validity of the tool. ${ }^{15-19}$ Hence, the Inlow's sixty second tool is found to be highly reliable for risk stratification of diabetic foot ulcers.

The 60-second diabetic foot risk stratification criteria is prepared by Inlow which aids primary care clinicians to identify the risks of diabetic foot (Figure 1). ${ }^{15}$

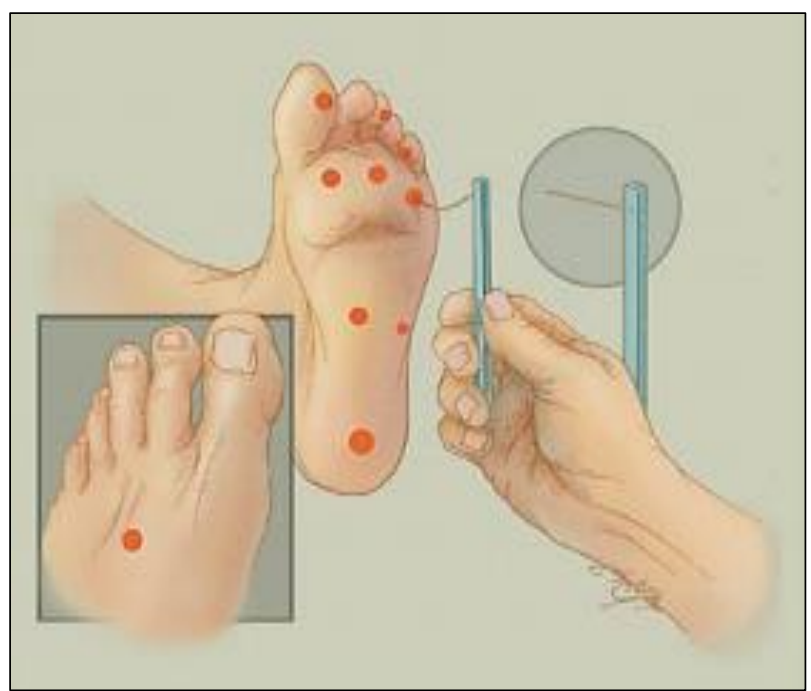

Source: Adopted from Sibbald ${ }^{21}$

Figure 1: Sensory foot examination.

This tool, also known as the 'Inlow's 60-Second Screen' was implemented into the bedside tool comprising of 12 items with a scoring system and an overall score that ranges from 0 to 23 . The tool is also validated in several settings of the healthcare sector wherein in some cases, the modified Inlow's tool is also used to suit different healthcare settings. ${ }^{20}$ It is further stated in validation studies that the Inlow's 60-second screen possesses high inter and intra rate reliability in the long term settings. ${ }^{16}$ Hence, such a tool could be used as a diabetic foot ulcer risk stratification tool and could reduce the risks of amputation in low and middle income nations such as India where the rate of foot amputation is high in the diabetic population (Table 1) (Figure 1).

There are only few studies which examined the reliability and credibility of the 60 second diabetic foot stratification tool and hence the credibility and reliability of the tool are least examined. Hence, a systematic review is conducted in the present paper which elaborates on the validity and credibility of the 60 second diabetic foot stratification tool. Furthermore, studies conducted on the risk stratification of foot ulcer among the Indian population are scarce. ${ }^{23}$ Hence, the paper also examines the feasibility of using the 60 second diabetic foot stratification tool in the Indian context since there is no research to reveal the applicability of the tool in Indian diabetic patients.

\section{METHODS}

\section{Search strategy and study selection}

The search for studies was performed electronically wherein various medical databases are searched such as EBSCO, MEDLINE (PubMed), NCBI, EMBASE, ISI and SCOPUS databases published up to December 2016. The use of Medical Subject Heading (MeSH) and keywords enabled the search for data for the systematic review. Following are the keywords that are included during the search: 'Diabetic foot ulcer (DFU); DFU risk stratification; 60 second DFU risk stratification tool, Inlow's 60 second risk stratification tool'. For the search of literature relevant to the aims of the paper, MeSH heading and keywords are used either in combination or independently.

For the collection of research articles with the aim to eliminate duplicate articles, language restriction and so on, the research focused on the PICO (Population, Intervention, Comparison and Outcome) methodology to elaborate on the inclusion parameters for the selection of appropriate researches in the review. Table 1 is the PICO table for the paper and table 2 is the criteria set for the selection of studies. (Table 2 and 3 )

The 'Assessment of methodological quality' is referred to as the appraisal of research articles critically which is the commonly used context in any systematic review. The examination of quality of articles removes bias wherein it is evident that only articles that are of high standards are considered for a systematic review.The use of Critical Appraisal Skills Programme (CASP) tool enables the 
assessment of the papers selected based on their qualities and check whether the selected studies could be included for the review. For both qualitative and quantitative studies, the CASP tool could be applied.

Table 1: Original inlow's 60-second diabetic foot screen.

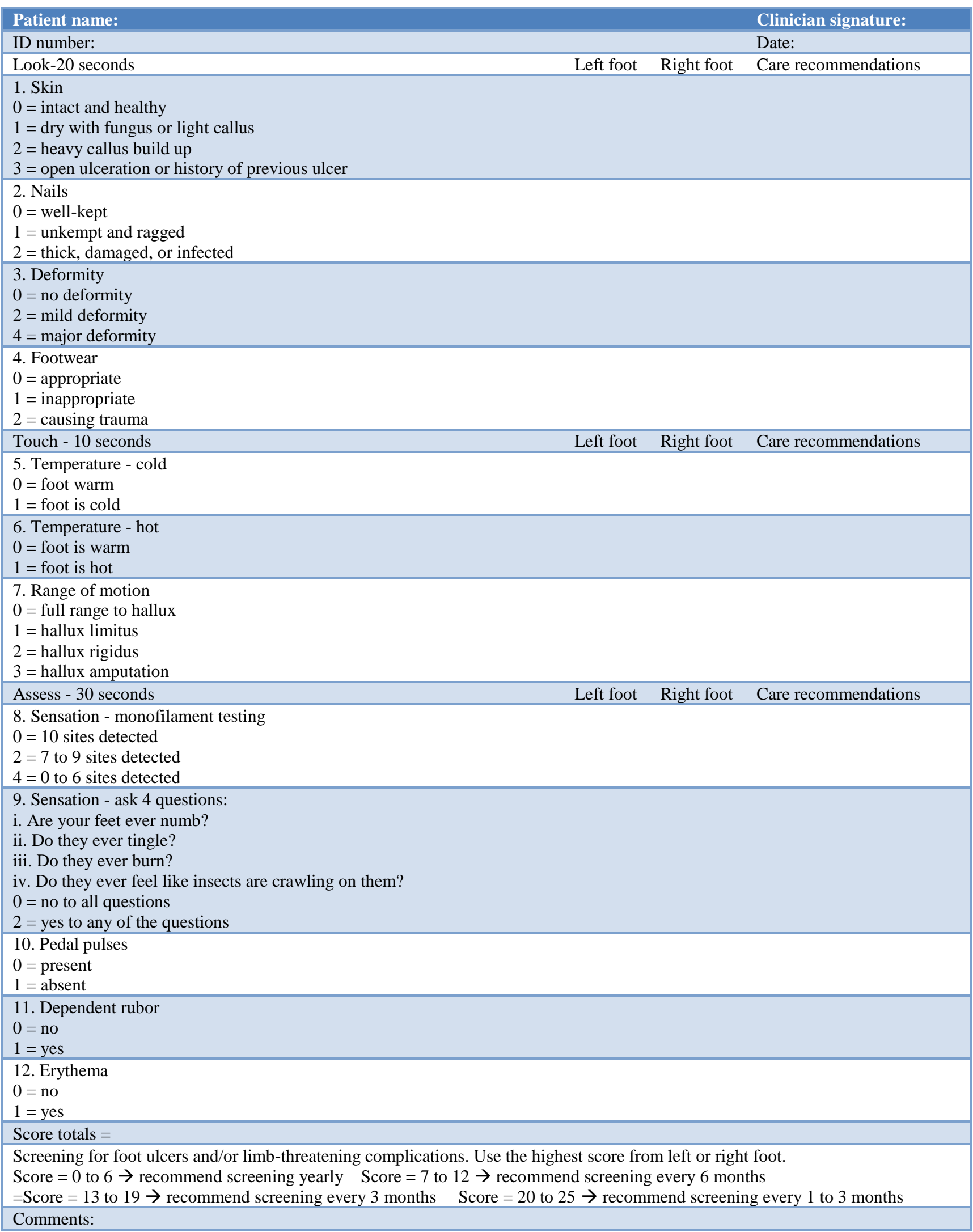

\section{Source: Adopted from Inlow ${ }^{21}$}


Table 2: PICOS methodology.

\begin{tabular}{|ll|}
\hline PICOS methodology & Patients with Diabetes \\
\hline Population or patient & The use of 60 second Diabetic foot risk stratification tool \\
\hline Intervention & - \\
\hline Comparison & 60 second Diabetic foot risk stratification tool as an effective \\
\hline Outcome & structured protocol for the assessment of diabetic foot ulcers \\
\hline
\end{tabular}

Table 3: Inclusion and exclusion criteria.

\section{Inclusion criteria $\quad$ Exclusion criteria}

Research articles which checked the validity and reliability Research articles that considered risk stratification tools of original and modified Inlow's 60 second risk stratification tool

Research articles published in English other than 60 second risk stratification tool

Research articles published in the period of 2012-2016

Research articles which lack data; incomplete information

Research articles from both developed and developing Studies which only had abstracts

nations

Research articles published in languages other than English

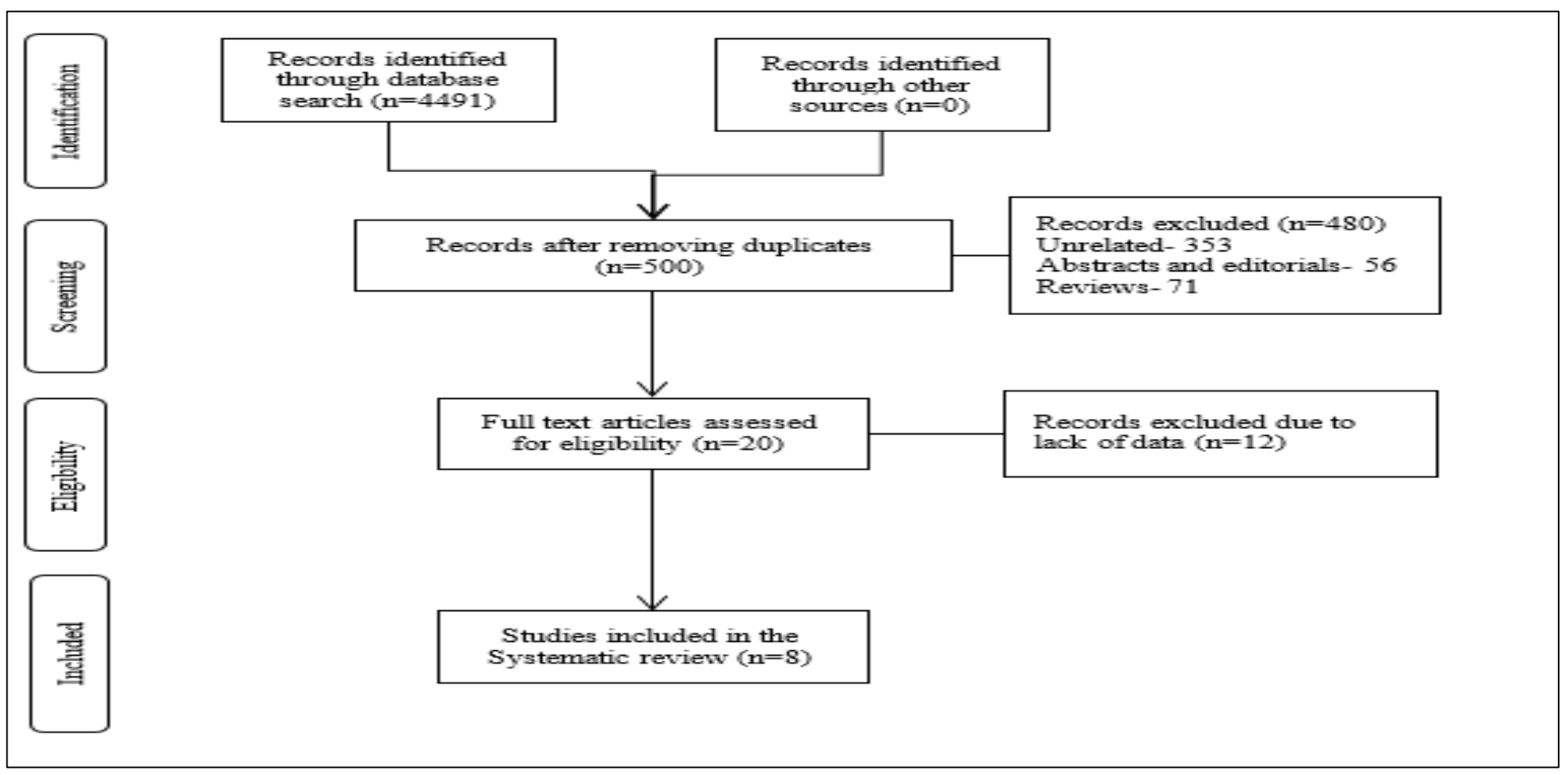

Figure 2: Article selection process.

\section{RESULTS}

\section{Description of the studies}

Our initial search for articles with respect to diabetic foot ulceration retrieved 4491 studies. With the application of the inclusion and exclusion criteria specified in Table 2, only 20 articles had relevance to the topic. Further screening the articles based on availability of ample data led to only 8 studies which are selected for the systematic review. The selection of studies is given in the prisma flow diagram (Figure 2).

\section{Characteristics of included studies}

Table 4 directly below the present section is the main characteristics of the studies included in the systematic review (Table 4). 
Table 4: Data extraction table.

\begin{tabular}{|c|c|c|c|c|c|c|c|c|}
\hline $\begin{array}{l}\text { Author; } \\
\text { year }\end{array}$ & Title & $\begin{array}{l}\text { Region of } \\
\text { study }\end{array}$ & $\begin{array}{l}\text { Study } \\
\text { objective }\end{array}$ & $\begin{array}{l}\text { Data } \\
\text { collectior } \\
\text { period }\end{array}$ & $\begin{array}{l}\text { Description of } \\
\text { the research }\end{array}$ & $\begin{array}{l}\text { Outcomes } \\
\text { (reliability and } \\
\text { validity) }\end{array}$ & results & Conclusion \\
\hline $\begin{array}{l}\text { Woodbury } \\
\text { et al. }{ }^{16}\end{array}$ & $\begin{array}{l}\text { Tool for } \\
\text { rapid and } \\
\text { easy } \\
\text { identificatio } \\
\mathrm{n} \text { of high } \\
\text { risk diabetic } \\
\text { foot: } \\
\text { validation } \\
\text { and clinical } \\
\text { pilot of the } \\
\text { simplified } \\
60 \text { second } \\
\text { diabetic foot } \\
\text { screening } \\
\text { tool }\end{array}$ & $\begin{array}{l}\text { Guyana, } \\
\text { South } \\
\text { America }\end{array}$ & $\begin{array}{l}\text { To determine } \\
\text { the } \\
\text { applicability, } \\
\text { clinical } \\
\text { performance } \\
\text { and inter-rater } \\
\text { reliability of } \\
\text { the } \\
\text { 'Simplified } 60 \\
\text { Second } \\
\text { Diabetic Foot } \\
\text { Screening } \\
\text { tool' as a } \\
\text { routine } \\
\text { diabetic foot } \\
\text { ulcer } \\
\text { screening } \\
\text { method }\end{array}$ & $\begin{array}{l}2008- \\
2010\end{array}$ & $\begin{array}{l}\text { A simplified } \\
60 \text { second tool } \\
\text { is developed } \\
\text { on the grounds } \\
\text { of the Inlow's } \\
\text { sixty second } \\
\text { tool }\end{array}$ & $\begin{array}{l}\text { A minimum } \\
\text { Cronbach's } \\
\text { alpha value of } \\
0.60 \text { is } \\
\text { acceptable. } \\
\text { monofilament } \\
\text { test- } 0.98 \text {; } \\
\text { active ulcer- } \\
0.97 \text {; previous } \\
\text { amputation- } \\
0.97 \text {; previous } \\
\text { ulcer- } 0.97 ; \\
\text { fixed ankle- } \\
0.91 ; \\
\text { deformity- } \\
0.87 ; \text { callus- } \\
0.87 \text {; absent } \\
\text { pulses- } 0.87 \text {; } \\
\text { fixed toe- } \\
0.80 ; \text { blisters- } \\
0.77 ; \text { ingrown } \\
\text { nail- } 0.72 \text {; } \\
\text { and fissures- } \\
0.55\end{array}$ & $\begin{array}{l}\text { The high } \\
\text { inter- } \\
\text { reliability of } \\
\text { the } \\
\text { components } \\
\text { reveals the } \\
\text { potential } \\
\text { ability of the } \\
\text { tool to be } \\
\text { used for DFU } \\
\text { risk } \\
\text { stratification }\end{array}$ & $\begin{array}{l}\text { Simplified } \\
60-\text { Second } \\
\text { Diabetic } \\
\text { Screening } \\
\text { Tool can be } \\
\text { used as a } \\
\text { reliable tool } \\
\text { for the } \\
\text { identification } \\
\text { of diabetic } \\
\text { skin } \\
\text { ulceration in } \\
\text { any income } \\
\text { setting }\end{array}$ \\
\hline Mwandri ${ }^{24}$ & $\begin{array}{l}\text { The } \\
\text { outcome of } \\
\text { using the } \\
60 \text {-second } \\
\text { diabetic foot } \\
\text { screen to } \\
\text { identify the } \\
\text { diabetic foot } \\
\text { at risk in } \\
\text { Tanzania }\end{array}$ & Tanzania & $\begin{array}{l}\text { To examine } \\
\text { the risk } \\
\text { pattern for the } \\
\text { development } \\
\text { of diabetic } \\
\text { foot } \\
\text { complications }\end{array}$ & $\begin{array}{l}\text { June 201( } \\
\text { Novembe } \\
2011\end{array}$ & $\begin{array}{l}\text { The } 60 \text {-second } \\
\text { tool is used in } \\
\text { Tanzanian } \\
\text { setting to } \\
\text { facilitate the } \\
\text { assessment of } \\
\text { foot ulceration } \\
\text { related with } \\
\text { diabetes in the } \\
\text { region }\end{array}$ & - & $\begin{array}{l}\text { - Male: } \\
\text { female- } \\
60: 40 \text { in } 50 \\
\text { patients } \\
\text { - Prevalent } \\
\text { risk factors } \\
\text { include the } \\
\text { following- } \\
\text { Fissures ( } 37 \\
\text { per cent), } \\
\text { calluses ( } 27 \\
\text { per cent), } \\
\text { fungal } \\
\text { lesions in } \\
\text { the toe-web } \\
\text { spaces ( } 27 \\
\text { per cent), } \\
\text { the presence } \\
\text { of an active } \\
\text { plantar ulcer } \\
\text { (8 per cent), } \\
\text { blisters (4 } \\
\text { per cent) } \\
\text { and } \\
\text { ingrowing } \\
\text { toenails (6 } \\
\text { per cent) }\end{array}$ & $\begin{array}{l}60 \text {-second } \\
\text { diabetic foot } \\
\text { screen has } \\
\text { simplified } \\
\text { the } \\
\text { assessment } \\
\text { of diabetic } \\
\text { foot ulcer in } \\
\text { Tanzania. }\end{array}$ \\
\hline $\begin{array}{l}\text { Carreau et } \\
\text { al. }{ }^{17}\end{array}$ & $\begin{array}{l}\text { A prospective, } \\
\text { descriptive } \\
\text { study to assess } \\
\text { the reliability } \\
\text { and usability c } \\
\text { a rapid foot } \\
\text { screen for } \\
\text { patients with } \\
\text { diabetes } \\
\text { mellitus in a }\end{array}$ & Canada & $\begin{array}{l}\text { To explore } \\
\text { the time for } \\
\text { completion of } \\
\text { the } \\
\text { assessment, } \\
\text { the content, } \\
\text { ease of } \\
\text { utilisation and } \\
\text { the reliability } \\
\text { of the } 60\end{array}$ & $\begin{array}{l}\text { Not } \\
\text { specifie } \\
\text { d }\end{array}$ & $\begin{array}{l}\text { Inlow's } 60 \text { - } \\
\text { second Diabetic } \\
\text { foot screen is } \\
\text { used as such to } \\
\text { examine various } \\
\text { factors such as } \\
\text { deformities, skin } \\
\text { nails, } \\
\text { temperature, } \\
\text { footwear, motior }\end{array}$ & $\begin{array}{l}\text { - The } \\
\text { reliability and } \\
\text { validity of the } \\
60 \text { second } \\
\text { tool are } \\
\text { assessed in } \\
\text { long-term and } \\
\text { acute care } \\
\text { settings. } \\
\text { - Inter-rater }\end{array}$ & $\begin{array}{l}\text { - } 39 \text { per cent } \\
\text { of } \\
\text { assessments } \\
\text { took a } \\
\text { maximum of } \\
7 \text { minutes. } \\
\text { However, the } \\
\text { inter- } \\
\text { reliability of } \\
\text { the tool is }\end{array}$ & $\begin{array}{l}\text { Revisions in } \\
\text { the sixty } \\
\text { second tool } \\
\text { are necessary } \\
\text { for } \\
\text { improving } \\
\text { the ease of } \\
\text { use of the } \\
\text { tool and the } \\
\text { reliability }\end{array}$ \\
\hline
\end{tabular}




\begin{tabular}{|c|c|c|c|c|c|c|c|c|}
\hline & $\begin{array}{l}\text { complex } \\
\text { continuing car } \\
\text { setting }\end{array}$ & & $\begin{array}{l}\text { second } \\
\text { Diabetic Foot } \\
\text { Screen }\end{array}$ & & $\begin{array}{l}\text { range, pulses, } \\
\text { erythema } \\
\text { sensation, and } \\
\text { dependent rubor }\end{array}$ & $\begin{array}{l}\text { reliability was } \\
\text { low with ICC } \\
0.608(95 \% \\
\text { confidence } \\
\text { interval } \\
0.349-0.781)\end{array}$ & relatively low & $\begin{array}{l}\text { and validity } \\
\text { of the tool }\end{array}$ \\
\hline $\begin{array}{l}\text { Murphy et } \\
\text { al. }{ }^{18}\end{array}$ & $\begin{array}{l}\text { Reliability } \\
\text { and } \\
\text { Predictive } \\
\text { Validity of } \\
\text { Inlow's 60- } \\
\text { Second } \\
\text { Diabetic Foot } \\
\text { screen tool }\end{array}$ & Canada & $\begin{array}{l}\text { To assess and } \\
\text { ascertain risk } \\
\text { recognition } \\
\text { consistency } \\
\text { of the Inlow's } \\
60 \text {-Second } \\
\text { Diabetic Foot } \\
\text { Screen Tool } \\
\text { for practice } \\
\text { setting }\end{array}$ & $\begin{array}{l}\text { Novem } \\
\text { ber } \\
2009 \text { - } \\
\text { April } \\
2010\end{array}$ & $\begin{array}{l}\text { The research } \\
\text { aimed at } \\
\text { determining } \\
\text { the inter-rater } \\
\text { reliability, } \\
\text { intrarater } \\
\text { reliability and } \\
\text { the predictive } \\
\text { validity of the } \\
60 \text { second } \\
\text { tool. }\end{array}$ & $\begin{array}{l}\text { Interrater and } \\
\text { intrarater } \\
\text { reliability and } \\
\text { validity }\end{array}$ & $\begin{array}{l}\text { - Intrarater } \\
\text { reliability: } \\
\text { LTC } 0.96 \\
(0.93-0.98) \\
\text { right foot, } \\
0.97 \text { (0.95- } \\
0.98) \text { left } \\
\text { foot; } \\
\text { dialysis } 1.00 \\
\text { right and } \\
1.00 \text { left } \\
\text { foot. } \\
\text { Interrater } \\
\text { reliability: } \\
\text { LTC } 0.92 \\
\text { (0.86-0.96) } \\
\text { right foot, } \\
0.93 \text { (0.87 - } \\
0.96) \text { left } \\
\text { foot; } \\
\text { dialysis } 0.83 \\
\text { (0.65 -0.92) } \\
\text { right foot } \\
\text { and left } \\
\text { foot. } \\
\text { - Predictive } \\
\text { validity: } 1 \\
\text { ulcer and } 1 \\
\text { amputation }\end{array}$ & $\begin{array}{l}\text { Inlow's tool } \\
\text { demonstrates } \\
\text { excellent } \\
\text { intrarater and } \\
\text { interrater } \\
\text { reliability } \\
\text { wherein } \\
\text { predictive } \\
\text { validity } \\
\text { information } \\
\text { is also } \\
\text { provided. }\end{array}$ \\
\hline $\begin{array}{l}\text { Lowe et } \\
\mathrm{al}^{25}\end{array}$ & $\begin{array}{l}\text { The Guyana } \\
\text { diabetes and } \\
\text { foot care } \\
\text { project: } \\
\text { improved } \\
\text { diabetic foot } \\
\text { evaluation } \\
\text { reduces } \\
\text { amputation } \\
\text { rates by } \\
\text { two-thirds } \\
\text { in a lower } \\
\text { middle } \\
\text { income } \\
\text { country }\end{array}$ & $\begin{array}{l}\text { Guyana, } \\
\text { South } \\
\text { America }\end{array}$ & $\begin{array}{l}\text { To create } \\
\text { changes in } \\
\text { the health } \\
\text { system } \\
\text { towards the } \\
\text { management } \\
\text { and } \\
\text { improvement } \\
\text { of foot care in } \\
\text { people with } \\
\text { diabetes and } \\
\text { reduce } \\
\text { diabetes } \\
\text { complications } \\
\text { such as lower } \\
\text { extremity } \\
\text { amputation }\end{array}$ & $\begin{array}{l}\text { July } \\
2010 \text { - } \\
\text { March } \\
2013\end{array}$ & $\begin{array}{l}\text { Simplified 60- } \\
\text { second } \\
\text { screening tool } \\
\text { as mentioned } \\
\text { by Woodbury } \\
\text { et al. }{ }^{16} \text { was } \\
\text { used in the } \\
\text { study. }\end{array}$ & - & $\begin{array}{l}\text { - Two } \\
\text { phases of } \\
\text { improving } \\
\text { foot and } \\
\text { diabetes } \\
\text { care were } \\
\text { rolled out } \\
\text { - } 68 \text { per cent } \\
\text { reduction in } \\
\text { major } \\
\text { amputations } \\
\text {; } 80 \text { per cent } \\
\text { reduction in } \\
\text { below knee } \\
\text { amputations } \\
\text {; above knee } \\
\text { amputations } \\
\text { remain } \\
\text { unchanged }\end{array}$ & $\begin{array}{l}\text { Improved } \\
\text { foot care } \\
\text { system with } \\
\text { the } \\
\text { simplified } 60 \\
\text { second tool }\end{array}$ \\
\hline Din et al. ${ }^{19}$ & $\begin{array}{l}\text { Prevalence } \\
\text { of risk } \\
\text { factors for } \\
\text { Egyptian } \\
\text { Diabetic } \\
\text { foot } \\
\text { ulceration }\end{array}$ & Egypt & $\begin{array}{l}\text { To examine } \\
\text { the risk } \\
\text { factors } \\
\text { associated } \\
\text { with diabetic } \\
\text { foot } \\
\text { ulceration in } \\
\text { the Egyptian } \\
\text { population } \\
\text { wherein the } \\
\text { prevalence of } \\
\text { these risk }\end{array}$ & 2014 & $\begin{array}{l}\text { Modified } \\
\text { Inlow's 60- } \\
\text { second } \\
\text { Diabetic Foot } \\
\text { screen is used } \\
\text { to determine } \\
\text { the risk factor } \\
\text { prevalence for } \\
\text { diabetic foot } \\
\text { ulcers }\end{array}$ & $\begin{array}{l}\text { Tool } \\
\text { reliability was } \\
\text { calculated } \\
\text { using } \\
\text { Cronbach, s } \\
\text { Alpha test } \\
\text { which equal } \\
0.96(0.93- \\
0.98) \text { right } \\
\text { foot, } 0.97 \\
(0.95-0.98) \\
\text { left foot. }\end{array}$ & $\begin{array}{l}\text { - More than } \\
47.9 \text { per } \\
\text { cent of } \\
\text { patients } \\
\text { have } \\
\text { potential } \\
\text { risks of foot } \\
\text { ulcer } \\
\text { - lack of } \\
\text { knowledge } \\
\text { regarding } \\
\text { diabetic foot }\end{array}$ & $\begin{array}{l}\text { Modified } \\
\text { Inlow's 60- } \\
\text { second } \\
\text { Diabetic foot } \\
\text { screen acts } \\
\text { as a viable } \\
\text { option for } \\
\text { the } \\
\text { identification } \\
\text { of potential } \\
\text { risk for } \\
\text { diabetic foot }\end{array}$ \\
\hline
\end{tabular}




\begin{tabular}{|c|c|c|c|c|c|c|c|}
\hline & & $\begin{array}{l}\text { factors is also } \\
\text { assessed }\end{array}$ & & & & $\begin{array}{l}\text { problem, } \\
\text { inappropriate } \\
\text { footwear and } \\
\text { the high } \\
\text { prevalence of } \\
\text { skin and nail } \\
\text { pathology are } \\
\text { found to be } \\
\text { associated } \\
\text { with diabetic } \\
\text { foot ulcers }\end{array}$ & ulcer. \\
\hline Bethel $^{26}$ & $\begin{array}{l}\text { In patients wit US } \\
\text { Type } 2 \\
\text { diabetes, what } \\
\text { impact does th } \\
\text { American } \\
\text { Diabetes } \\
\text { Association } \\
\text { foot care } \\
\text { guidelines hav } \\
\text { in preventing } \\
\text { lower extremil } \\
\text { complications' }\end{array}$ & $\begin{array}{l}\text { To determine } \\
\text { the impact of } \\
\text { ADA foot care } \\
\text { guidelines on } \\
\text { the developmen } \\
\text { of lower } \\
\text { extremity } \\
\text { complications is } \\
\text { type two } \\
\text { diabetics. }\end{array}$ & $\begin{array}{l}\text { July } \\
2014 \text { - } \\
\text { March } \\
2015\end{array}$ & $\begin{array}{l}\text { - A diabetic } \\
\text { lower extremity } \\
\text { educational } \\
\text { intervention } \\
\text { which is based } \\
\text { on the } \\
\text { guidelines of } \\
\text { ADA was } \\
\text { provided. } \\
\text { - To conclude } \\
\text { whether ADA } \\
\text { guidelines are } \\
\text { followed }\end{array}$ & - & $\begin{array}{l}\text { - The } 60 \\
\text { second Tool } \\
\text { is used for } \\
\text { the } \\
\text { screening of } \\
\text { High-Risk } \\
\text { Diabetic } \\
\text { Foot }\end{array}$ & $\begin{array}{l}\text { Adherence to } \\
\text { the ADA } \\
\text { guidelines } \\
\text { for foot care } \\
\text { for lower } \\
\text { extremity } \\
\text { complication } \\
\text { reduction, } \\
\text { has the } \\
\text { potential to } \\
\text { significantly } \\
\text { improve } \\
\text { patient } \\
\text { outcomes in } \\
\text { Type } 2 \\
\text { diabetes } \\
\text { patients }\end{array}$ \\
\hline $\begin{array}{l}\text { Mamo et } \\
\text { al. } .^{27}\end{array}$ & $\begin{array}{l}\text { Risk factors Ethiopia } \\
\text { assessment of } \\
\text { Diabetic foot } \\
\text { ulcer using } \\
\text { the sixty } \\
\text { seconds } \\
\text { screening } \\
\text { tool: a } \\
\text { hospital } \\
\text { based cross- } \\
\text { Sectional } \\
\text { study At } \\
\text { Tikur } \\
\text { Anbessa } \\
\text { specialized } \\
\text { hospital }\end{array}$ & $\begin{array}{l}\text { To introduce } \\
\text { the } 60 \text {-second } \\
\text { DFU } \\
\text { screening tool } \\
\text { as a basis for } \\
\text { routine } \\
\text { follow-up of } \\
\text { patients with } \\
\text { diabetes and } \\
\text { to assess the } \\
\text { characteristic } \\
\text { s and } \\
\text { prevalence of } \\
\text { the DFU risk } \\
\text { factors }\end{array}$ & $\begin{array}{l}\text { April } \\
\text { 2014- } \\
\text { August } \\
2014\end{array}$ & $\begin{array}{l}\text { - A cross } \\
\text { sectional study } \\
\text { involving } \\
\text { clinical } \\
\text { diagnosis of } \\
\text { diabetic foot } \\
\text { ulcers using } \\
\text { the } 60 \text { seconds } \\
\text { screening tool }\end{array}$ & - & - & $\begin{array}{l}\text { Diabetic foot } \\
\text { ulcer } \\
\text { screening, } \\
\text { despite an } \\
\text { easy practice } \\
\text { is barely } \\
\text { practiced for } \\
\text { outpatients } \\
\text { visiting the } \\
\text { diabetic } \\
\text { clinics and } \\
\text { hence a need } \\
\text { persists to } \\
\text { clinically } \\
\text { diagnose } \\
\text { diabetic foot } \\
\text { ulcers using } \\
\text { the } 60 \\
\text { seconds } \\
\text { screening } \\
\text { tool. }\end{array}$ \\
\hline
\end{tabular}

\section{DISCUSSION}

The present paper is a systematic review which attempts to examine the validity and reliability of the 60 second Diabetic Foot ulcer risk stratification tool developed by InLow. ${ }^{15}$ It is evident that for patients with diabetes, podiatry care should be available as a routine technique; however almost in all healthcare systems worldwide, especially in the developing nations, there are limited podiatry resources which makes provision of routine foot care impossible for diabetic patients. Furthermore, Pham et al, state that for diabetic foot ulcerations, isolated clinical assessment is identified as risk markers. ${ }^{27}$ Foot screening is hence identified as an important process which is deemed to reduce complications occurring in the foot for patients with diabetes. According to Boike and Hall, for diabetic patients, routine foot examinations are important as diabetes is associated with neuropathic and circulatory breakdowns which leads to ulceration and amputation. ${ }^{28,29}$ The Inlow's 60 second foot examination tool is used for the examination of diabetic patients' foot. ${ }^{30}$ For a healthy well-being and optimal wound healing, comprehensive wound screening tools are important. The 60 second foot screening tool is developed by researchers as a simple tool that can screen diabetic foot ulcers. The same is also used by healthcare 
professionals all over the world; however, the routine use of the tool is still lacking especially in the developing nations.

An unmodified Inlow's 60-second diabetic foot screen comprises of the following parts: a) Examination of the feet and shoes; b) Feet palpation; c) Conducting sensory screen and examination. ${ }^{31}$ The 60 -Second Diabetic Foot Screen tool requires considerable amount of time (in minutes) to assess the foot of diabetic patients wherein it requires a 10-g monofilament and an assessor with clinical assessment skills. The tool further lets the clinician to assign values to the different elements used in the screening tool wherein 12 elements are used. On the basis of value acquired for each category, recommendations and foot care plans can be provided. The tool further prompts clinical experts to refer care and provide timely assistance to patients. ${ }^{32}$

With the benefits of the Inlow's 60 second diabetic tool analysed, a systematic review is conducted wherein the inclusion and exclusion criteria were set to screen research articles. An extensive search of previous researches revealed that only eight studies fit to the requirements of the systematic review and the objectives of the paper. All studies attempted to examine the risks of diabetic foot ulcers, its association with amputation and how the 60 -second tool could be administered by clinicians to assess the risks of diabetic foot ulcers. It is revealed that five studies utilized the Inlowe's 60 second risk stratification tool without any modifications or additions to the tool. In the study by Mwandri et al, the case of Tanzania was considered wherein it was revealed that more than 35 per cent of patients referred to diabetic unit in tertiary hospitals suffer from diabetic foot complications. ${ }^{24}$ The 60 second tool was used wherein proper use of the tool was ascertained prior conducting the study. Carreau et al, further revealed that Inlow's 60second Diabetic Foot Screen was used in a complex continuing care setting for the assessment and ease of use of the tool in Canada. ${ }^{16}$ Murphy et al, state that Inlow's 60-Second Diabetic Foot screen tool acts as a reliable method for the assessment and prediction of amputations or diabetic foot ulcers wherein the study similar to Carreau et al was conducted in Canada. ${ }^{17-18}$ Bethel et al conducted a US based research wherein the 60 second risk stratification tool was used for the screening of HighRisk Diabetic Foot. ${ }^{26}$ Mamo et al, conducted a hospital based cross-sectional study wherein 60 second diabetic foot ulcer screening tool was used as a cost effective method to prevent foot ulcers. ${ }^{27}$ In almost all the five studies, it was revealed that further modifications are required in the Inlowe's 60 second tool for ease of use of the tool and consistency. Carreau et al and Murphy et al directly state the need for revising the tool which further leads to the testing in the specific settings considered in the research. ${ }^{17-18}$ Mamo et al, indirectly revealed the need for modification of the 60 second tool which then becomes a conventient tool to assess diabetic foot ulcers even during busy outpatient visiting hours. ${ }^{26}$
However, considering the need for modifications or revisions in the Inlowe's 60 second tool, three studies utilised the simplified or modified 60 second tool. Woodbury et al, utilised the simplified 60 second tool which had sections to acquire information on previous history of ulcers or amputations, physical examination of the foot, foot lesions, and neuropathy. ${ }^{16}$ The same tool is used by Lowe et al, wherein both the researches are conducted in Guyana, South America. The simplified screening tool acts as a method for structured management of diabetic foot with high risks wherein the guidelines referred pertain to the international clinical practice guidelines. ${ }^{24}$ Furthermore, it provides intense management information for the prevention of diabetic foot ulcers as the inter-rater reliability of the components in the tool is relatively high. Furthermore, it acts as tool with potential utility (Figure 3 ). ${ }^{15}$

Four studies in-depth considered the examination of the validity and reliability of the tool wherein several recommendations were put forth by the researchers. ${ }^{16-19}$ Woodbury et al, revealed excellent inter-rater reliability of the components in the 60 second tool wherein only one study by Carreau et al, revealed the low value of interrater reliability (ICC 0.608 [95\% confidence interval $0.349-0.781]$ ) which was associated with variations in the interpretations associated with the assessment of patient population parameters. ${ }^{15,16}$ Furthermore, it is evident from studies by Woodbury et al and Din et al, which utilised modified 60 second tool whereas Carreau et al, used the Inlowe's 60 second tool as such. ${ }^{15,16,18}$ Hence, revisions are important for the 60 second tool to improve ease of use, consistency, validity and reliability.

However, there is a need to examine the feasibility of utilising the 60 second tool in the context of developing nations, especially in India which has high incidence of diabetes. India is one among the nations with diabetes mellitus as an epidemic making the nation to possess the second highest number of diabetic patients in the world. An approximation is given by International Diabetes Federation which states that around 69 million individuals in India suffer from disease as of 2015. ${ }^{34} \mathrm{~A}$ recent research conducted in India stated that the costs for diabetes care for patients with foot ulcers is four times higher than that of patients without ulcers wherein the cost is US\$409 for patients with foot ulcers and US\$97 for diabetic patients without foot ulcers. ${ }^{35}$ Hence for the reduction of foot complications due to diabetes, effective strategies are required. Though the indicators and goals set for foot care in developed and developing nations are similar, there are differences in the availability of resources to treat the same (both economic and human resources) in India. Such an unfortunate situation reveals the need for other therapeutic strategies, approaches and methods for successful diabetic foot infection management. ${ }^{36}$ 


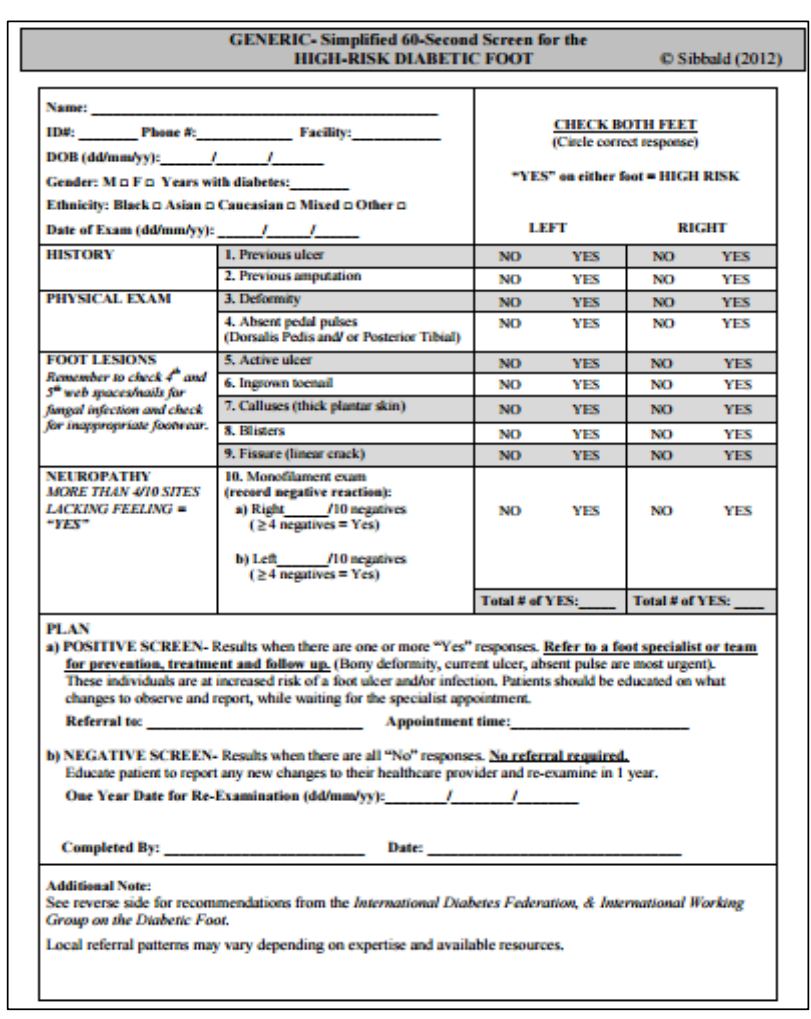

Figure 3: Modified 60 second diabetic foot screen tool.

Considering the importance of managing the complications of diabetes, especially foot ulceration and amputation in the Indian scenario, it is evident from the examination of previous researches that the 60 second screening tool can act as a viable option to identify, prevent, and manage diabetic foot ulcers in the Indian population as the results of five studies relate to the context of developing nations. A summary of the key recommendations and key measures for the treatment of diabetic foot ulcers is given by Indian Health Service Division of Diabetes Treatment and Prevention which revealed the following best outcomes in India. ${ }^{36}$

\section{Criteria for high risk feet with diabetes}

10-g monofilament testing; examination of foot deformity; prior history of ulceration or amputation; absence of pulse or abnormal pressure in Ankle-Brachial Index (ABI); with the examination of the risks of diabetic foot ulcers, foot care education will be provided by directing the patients to examine and control blood pressure and glucose, and lipid levels for the prevention of neuropathy and Peripheral Vascular Disease (PVD).

These guidelines are covered by the 60 second foot screening tool devised by Inlowe. For the Indian context, the guidelines could be further modified with respect to ease of use and convenience by clinicians as India is a populous nation with diabetic clinics, the most intensive units with high outpatient appearance. This fact is further strengthened by Mamo et al, who stated that the 60 second screening tool is a convenient option to screen patients even during busy outpatient hours which are evident in India. ${ }^{26}$ Studies have further revealed that the application of the 60 second foot screening tool is suitable in the developing nations scenario and hence the same could be applied in India.

According to Woodbury et al, the development of the simplified 60 second risk stratification tool is a reverse innovation concept wherein the tool is re-innovated for bringing diabetic foot care even to low and middle income nations. ${ }^{15}$ Furthermore, Mwandri et al, state that the simplification and promptness of the 60 second screening tool makes it an effective method for the assessment of diabetic foot ulcers in developing nations. ${ }^{23}$ Furthermore, early recognition and prevention of diabetic foot ulcer complications though the use of the 60 second tool might improve quality of life and reduce healthcare associated costs and hence the tool is suitable for a middle income country like India. ${ }^{17}$

\section{CONCLUSION}

At present, the systematic review has revealed the feasibility of using the 60 second risk diabetic foot ulcer risk stratification tool in the Indian context as most studies selected for the present paper claim the application of the tool in low and middle-income nations. However, future studies are recommended to examine the feasibility of the tool in Indian scenario through a crosssectional/prospective study wherein the reliability and validity of the 60 second tool need to be examined in the Indian context.

Furthermore, future studies should also take into account the need for modifications/revisions of the 60 second tool for its application in India.

Funding: No funding sources

Conflict of interest: None declared

Ethical approval: Not required

\section{REFERENCES}

1. Mathers CD, Loncar D. Projections of global mortality and burden of disease from 2002 to 2030 . PLoS Med. 2006;3(11):e442.

2. $\mathrm{Wu} \mathrm{SC}$, Driver VR, Wrobel JS, Armstrong DG. Foot ulcers in the diabetic patient, prevention and treatment. Vasc Health Risk Manag. 2007;3(1):6576.

3. Jeffcoate W, Bakker K. World Diabetes Day: footing the bill. Lancet (London, England). 2005;365(9470): 1527.

4. Boulton AJM, Vileikyte L, Ragnarson-Tennvall G, Apelquist J. The global burden of diabetic foot disease. Lancet (London, England). 2005;366(9498):1719-24.

5. Wild S, Roglic G, Green A, Sicree R, King H. Global prevalence of diabetes: estimates for the year 
2000 and projections for 2030. Diabetes Care. 2004;27(5):1047-53.

6. Boulton AJ, Vileikyte L. The diabetic foot: The scope of the problem. J Fam Pract. 2000;49(11):S38.

7. Singh N, Armstrong DG, Lipsky BA. Preventing foot ulcers in patients with diabetes. JAMA. 2005;293(2):217-28.

8. International Diabetes Federation. IDF Diabetes Atlas Sixth Edition Brussels, Belgium: International Diabetes Federation. $6^{\text {th }}$ ed. Belgium: International Diabetes Federation; 2013:1-169.

9. Boulton AJM, Armstrong DG, Albert SF, Frykberg RG, Hellman R, Kirkman MS, et al. Comprehensive foot examination and risk assessment: a report of the task force of the foot care interest group of the American Diabetes Association, with endorsement by the American Association of Clinical Endocrinologists. Diabetes Care. 2008;31(8):167985 .

10. Apelqvist J, Bakker K, van Houtum WH, Schaper NC. Practical guidelines on the management and prevention of the diabetic foot. Diabetes Metab Res Rev. 2008;24(S1):S181-7.

11. Crawford $F$, Inkster $M$, Kleijnen $J$, Fahey $T$. Predicting foot ulcers in patients with diabetes: a systematic review and meta-analysis. QJM. 2006;100(2):65-86.

12. Boyko EJ, Ahroni JH, Cohen V, Nelson KM, Heagerty PJ. Prediction of Diabetic Foot Ulcer Occurrence using commonly available clinical information: the Seattle diabetic foot study. Diabetes Care. 2006;29(6):1202-7. Available from: http://care.diabetesjournals.org/cgi/doi/10.2337/dc0 5-2031

13. Monteiro-Soares M, Boyko EJ, Ribeiro J, Ribeiro I, Dinis-Ribeiro M. Risk stratification systems for diabetic foot ulcers: a systematic review. Diabetol. 2011;54(5):1190-9.

14. Inlow $\mathrm{S}$. The 60 -second foot exam for people with Diabetes. Wound Care Ca. 2004;2(2):10-1.

15. Woodbury MG, Sibbald RG, Ostrow B, Persaud R, Lowe JM. Tool for rapid and amp; easy identification of high risk diabetic foot: validation and amp; Clinical Pilot of the Simplified 60 Second Diabetic Foot Screening Tool. Santanelli, di Pompeo d'Illasi F, editor. PLoS One. 2015;10(6):e0125578.

16. Carreau L, Niezgoda H, LeBlond S, Trainor A, Orsted H, Woodbury MG. A prospective, descriptive study to assess the reliability and usability of a rapid foot screen for patients with diabetes mellitus in a complex continuing care setting. Ostomy Wound Manage. 2013;59(1):28-34.

17. Murphy CA, Laforet K, Da Rosa P, Tabamo F, Woodbury MG. Reliability and predictive validity of Inlow's 60-Second Diabetic Foot Screen Tool. Adv Skin Wound Care. 2012;25(6):261-6.
18. Din SA El, Mekkawy MM, Besely WN, Azer` SZ. Prevalence of risk factors for Egyptian diabetic foot ulceration. IOSR J Nurs Heal Sci. 2016;5(2):45-57.

19. Orsted H. Development of the Inlow 60- second Diabetic foot screen: a practice-ready bedside tool to guide assessment and care. Wound Care Can. 2009; 7(2):40-2.

20. Inlow S. 60-second Diabetic foot screen. Can Assoc wound Care. 2004;2(2):10-1.

21. Sibbald. Screening for the high risk diabetic foot: a 60-Second Tool. Modif from Int Diabetes Fed Int Work Gr Diabet Foot. 2008;1-2.

22. Dominic A, Kumari MJ, S DSB, Sheela AM. Risk stratification of Diabetic foot ulcers among the Patients with Diabetes mellitus at a tertiary care Hospital. Int J Adv Res. 2013;3(9):923-7.

23. Mwandri M. The outcome of using the 60 -second diabetic foot screen to identify the diabetic foot at risk in Tanzania. Wound Heal South Africa. 2012;5(2):1-4.

24. Lowe J, Sibbald RG, Taha NY, Lebovic G, Martin $\mathrm{C}$, Bhoj I, et al. The Guyana diabetes and foot care project: a complex quality improvement intervention to decrease diabetes-related major lower extremity amputations and improve diabetes care in a lower-middle-income country. PLoS Med. 2015;12(4).

25. Bethel KR. In patients with Type 2 diabetes, what impact does the American Diabetes Association foot care guidelines have in preventing lower extremity complications?. 2015. Available at http://www.nursinglibrary.org/vhl/handle/10755/577 474.

26. Mamo $\mathrm{T}$, Yifter $\mathrm{H}$, Lemessa $\mathrm{T}$. Risk factors assessment of diabetic foot ulcer using the sixty seconds screening tool: a hospital based crosssectional study at Tikur Anbessa specialized Hospital. Ethiop Med J. 2015;2:45-9.

27. Pham H, Armstrong DG, Harvey C, Harkless LB, Giurini JM, Veves A. Screening techniques to identify people at high risk for diabetic foot ulceration: a prospective multicenter trial. Diabetes Care. 2000;23(5):606-11.

28. Boike AM, Hall JO. A practical guide for examining and treating the diabetic foot. Cleve Clin J Med. 2002;69(4):342-8.

29. American Diabetes Association. Standards of Medical Care in Diabetes-2010. Diabetes Care. 2010;33(1):S11-61.

30. Sibbald RG, Ayello EA, Alavi A, Ostrow B, Lowe $\mathrm{J}$, Botros $\mathrm{M}$, et al. Screening for the high-risk diabetic foot: a 60-second tool (2012). Adv Skin Wound Care. 2012;25(10):465-76.

31. McDonald A, Shah A, Wallace WC. Diabetic foot education and Inlow's 60-second foot screen. Diabet Foot Canada. 2013;1(1):18-32.

32. Bakker $\mathrm{K}$, Acker $\mathrm{K}$ van. International Working Group on the Diabetic Foot. International Diabetes Federation; 2017. Available from: http://iwgdf.org/ 
33. Sibbald. Generic- simplified 60-second screen for the high-risk diabetic foot. Modif from Int Diabetes Fed Int Work Gr Diabet Foot. 2008;1-2. International Diabetes Federation. Diabetes Federation. IDF Diabetes Atlas, seventh edition. International Diabetes Federation; 2017. Available at http://www.diabetesatlas.org.

34. Kumpatla S, Kothandan H, Tharkar S, Viswanathan V. The costs of treating long-term diabetic complications in a developing country: a study from India. J Assoc Physicians Ind. 2013;61(2):102-9.

35. Apelqvist J, Bakker K, van Houtum WH, NabuursFranssen MH, Schaper NC. International consensus and practical guidelines on the management and the prevention of the diabetic foot. International Working Group on the Diabetic Foot. Diabetes Metab Res Rev. 2000;16:S84-92.
36. Foot Care. Indian health diabetes best practice foot care. Indian Health Service Division of Diabetes Treatment and Prevention; 2011. Available at https://webcache.googleusercontent.com/search?q=c ache:PJ7aK7xy3kMJ:https://www.ihs.gov/MedicalP rograms/Diabetes/HomeDocs/Tools/BestPractices/2 011_BP_FootCare_508c.pdf $+\& \mathrm{~cd}=9 \& \mathrm{hl}=\mathrm{en} \& \mathrm{ct}=\mathrm{cl}$ $\mathrm{nk} \& \mathrm{gl}=\mathrm{in}$.

Cite this article as: Parasuraman M, Giridharan B, Vijayalakshmi G. Reliability and credibility analysis of Inlow's 60 second diabetic foot screening tool for diabetic foot risk stratification and its feasibility in India: a systematic review. Int Surg J 2017;4:287888. 